\title{
末梢神経切断による骨格筋線維の変化 に関する組織学的研究
}

\author{
菊地邦雄 \\ （昭和48年 7 月 24 日受付）
}

\section{Histological Study on the Change in Skeletal Muscle Fibers after the Cutting of Peripheral Nerve}

\author{
Kunio Kikuchi \\ (Faculty of General Education, Hiroshima University)
}

末梢神経切断による骨格笳線維の萎縮の現象を追求するために，同腹のWistar 系ラットの倠雄を脚，生後 70日目K M. tibialis ant. を支配する N. fibularis profundus を切断したのち, 10日目, 20日目飞組織学的検 討を行い，次のような成績を得た。

（1）神経切断による体重の诚少はみとめられない.

（2） M. tibialis ant. の重量は，神経切断後10日目では28.4\%，20日目では39.8\%の娍少を示した.

（3） M. tibialis ant. の全横断面積の萎縮率は，神経切断後10日目では赤笳線維 $19.3 \%$ ，中間筋線維 $34.7 \%$, 白筋線維 $43.7 \%$ 示した.

（4） M. tibialis ant. の一本あたりの平均横断面積の萎縮率は，神経切断後10日目で赤筋線錐 $13.2 \%$ ，中間筋 線維 $19.6 \%$, 白筋線維 $33.9 \%$ を示し，全横断面積の場合と同じ傾向を示した.

The atrophy of muscle fibers after the cutting of $\mathrm{N}$. fibularis profundus to $\mathrm{M}$. tibialis ant. was studied histologically by making a distinction among red muscle fibers, medium muscle fibers and white muscle fibers.

The experimental animals, Wistar-strain rats, were devided into two groups, namely the nerve-cutting group and the control group. In the nerve-cutting group, $N$. fibularis profundus was cut on the 70 days after birth. M. tibialis ant. was removed on the 10 days and 20 days after the cutting of nerve.

The histological method, using Sudan black B stain, was adopted.

The results obtained were as follows:

1) No apparent effect of the nerve cutting on the rats' body weight could be observed.

2) The decreasing rate of the weight of $\mathrm{M}$. tibialis ant. was $28.4 \%$ on the 10 days and $39.8 \%$ on the 20 days after the nerve cutting.

3 ) In the group of the 10 days after the nerve cutting, the decreasing rate of the entire area of cross section at the middle part of $\mathrm{M}$. tibialis ant. was $19.3 \%$ in red muscle fibers, $34.7 \%$ in medium muscle fibers, and $43.7 \%$ in white muscle fibers. 
4) The effect of the nerve cutting on the average area of cross section per fiber showed the same tendency as that on the entire area of cross section in red muscle fibers, medium muscle fibers and white muscle fibers.

(Kikuchi, K.: Histological Study on the Change in Skeletal Muscle Fibers after the Cutting of Peripheral Nerve, Research Journal of Physical Education, Vol. 18, No. 3, December, 1973. pp. 145 152)

\section{䜕}

骨格筋線維の萎縮について，南》は神経切断や ギプス固定の際の変性筋をつくり，骨格筋線維を 赤肪線維, 白筋線維に分けて組織学的に検討して いる。また，日野る)は末梢神経㧍よび骨格筋に外 科的侵意を加えた際の骨格筇線維の変化について 稩胞学的な検討を行っている. しかし，骨格筋線 維を赤肪線維, 中間筋線維および白筋線維に分け て筋萎䋧の現象を追求した資料はみられない。

著者臬は，すでに中間筋楾維の形態的特徽と分 布，および筋トレーニングを行った場合の筋肥大 の様相について，赤筋線維，白筋線維と比較しな がら埌告したが，本研究では，支配神経切断によ る骨格筇線維の萎樎の現象を赤筋線維, 中間筋線 維および白筋線維に分類して組織学的に検討する ことを試みた。

\section{实 方 法}

同腹の Wistar 系ラットの皆雄 (12例) を用 い，生後70日目に M. tibialis ant. を支配するN. fibularis profundus を脛骨頭の部位で，長さ約 5 $\mathrm{mm}$ を切断したのち，10日目，20日目に M. tibialis ant. の顕微鏡標本を作成して組織学的㭘討 を行った.

実験クループは，次の 5 群に設定した。

（1）生後70日の対照群

（2）神経切断後10日目（生後80日）の実験群

（3）神経切断後10日目（生後80日）の対照群

（4）神経切断後20日目 (生後90日) の実験群

（5）神経切断後20日目 (生後90日) の対照群

なお，神経切断後10日目および20日目の各対炤 群の設定には，それぞれ実験群の煡 㑡の M. tibialis ant. を選んだ.

顕微鏡標本作成の手順は，次のとおりである. a ）固定：被検筋を10\%ホルマリンに浸液し， 約 3 週間固定する.

b ）包埋：固定した筋肉をぜラチン液（1\%の 石炭酸 $30 \mathrm{cc}$ ，ヒラチン粉末 $10 \mathrm{~g}$ の割合）に入れ て, 約 24 時間恒温槽で包埋する。

c）薄切：Sartrius 型ミクロトームを用い，電

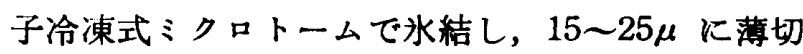
して染色する.

d) 染色：染色は，脂肪染色の Sudan black B を使用した Lison 氏法量である。染色時間は組織 の種類，液温によって異なるが，約30分である.

筋線維の横断面皘の測定は. 顕销鏡写真をとり， 筋線維每に写真印画紙を切り抜き，赤筇線維，中 間筋線維および白筋線維に分けて科量し，重さか ら面積に換算する方法をとった。

ラットの飼育には，オリエンタル固型飼料を用 い. 室温は $18^{\circ} \sim 22^{\circ} \mathrm{C}$ になるよ5に注意した。

\section{实 赫 果}

1）ラットの体重および下肢笳重量の変化

ラットの体重変化について. 生後 3 週間目から 雌雄別に検討した結果は図1に示すとおりであ

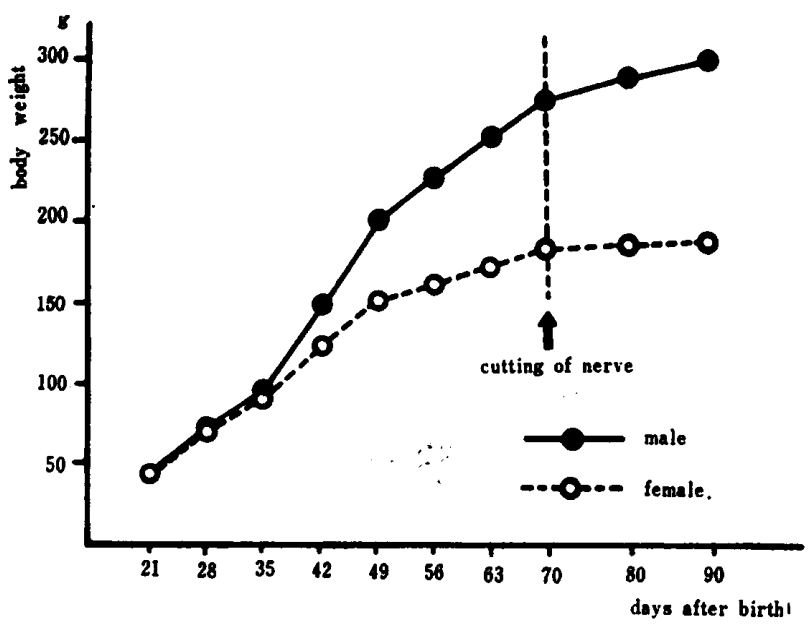

Fig. 1 Variation of Rats' Body Weight. 
Table 1 Effect of Cutting of Nerve upon Weight of Each Muscle of Rats' Lower Limbs

\begin{tabular}{|c|c|c|c|c|c|c|c|}
\hline & & Sex & $\begin{array}{l}\text { M. tibialis } \\
\text { ant. }\end{array}$ & $\begin{array}{l}\text { M. gastrocne- } \\
\text { mius }\end{array}$ & M. soleus & M. plantalis & $\begin{array}{l}\text { M. ext. } \\
\text { longus }\end{array}$ \\
\hline \multirow{3}{*}{ (1) } & \multirow{3}{*}{$\begin{array}{l}\text { control group of } 70 \\
\text { days after birth }\end{array}$} & $\delta$ & $0.568 \mathrm{~g}$ & $1.680 \mathrm{~g}$ & $0.552 \mathrm{~g}$ & $0.128 \mathrm{~g}$ & $0.144 \mathrm{~g}$ \\
\hline & & $q$ & 0.322 & 1.028 & 0.370 & 0.080 & 0.088 \\
\hline & & Mean & 0.445 & 1.353 & 0.461 & 0.104 & 0.116 \\
\hline \multirow{3}{*}{ (2) } & \multirow{3}{*}{$\begin{array}{l}\text { nerve cutting } \\
\text { group of } 80 \text { days } \\
\text { after birth } \\
\left(\begin{array}{l}10 \text { days after } \\
\text { nerve cutting }\end{array}\right)\end{array}$} & $\delta$ & 0.426 & 1.648 & 0.564 & 0.154 & 0.112 \\
\hline & & $q$ & 0.284 & 1.148 & 0.390 & 0.100 & 0.084 \\
\hline & & Mean & 0.355 & 1.398 & 0.477 & 0.127 & 0.098 \\
\hline \multirow{3}{*}{ (3) } & \multirow{3}{*}{$\begin{array}{l}\text { control group of } 80 \\
\text { days after birth }\end{array}$} & $\delta$ & 0.644 & 1.706 & 0.556 & 0.130 & 0.140 \\
\hline & & 8 & 0.348 & 1.220 & 0.414 & 0.100 & 0.086 \\
\hline & & Mean & 0.496 & 1.463 & 0.485 & 0.127 & 0.113 \\
\hline \multirow{3}{*}{ (4) } & \multirow{3}{*}{$\begin{array}{l}\text { nerve cutting } \\
\text { group of } 90 \text { days } \\
\text { after birth } \\
\left(\begin{array}{l}20 \text { days aftes } \\
\text { nerve cutting }\end{array}\right)\end{array}$} & $\delta$ & 0.310 & 1.540 & 0.528 & 0.130 & 0.094 \\
\hline & & 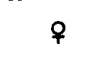 & 0.240 & 1.198 & 0.410 & 0.104 & 0.074 \\
\hline & & Mean & 0.275 & 1.369 & 0.469 & 0.117 & 0.084 \\
\hline \multirow{3}{*}{ (5) } & \multirow{3}{*}{$\begin{array}{l}\text { control group of } 90 \\
\text { days after birth }\end{array}$} & $\delta$ & 0.540 & 1.724 & 0.524 & 0.126 & 0.128 \\
\hline & & 9 & 0.374 & 1.192 & 0.408 & 0.111 & 0.090 \\
\hline & & Mean & 0.457 & 1.458 & 0.466 & 0.119 & 0.109 \\
\hline
\end{tabular}

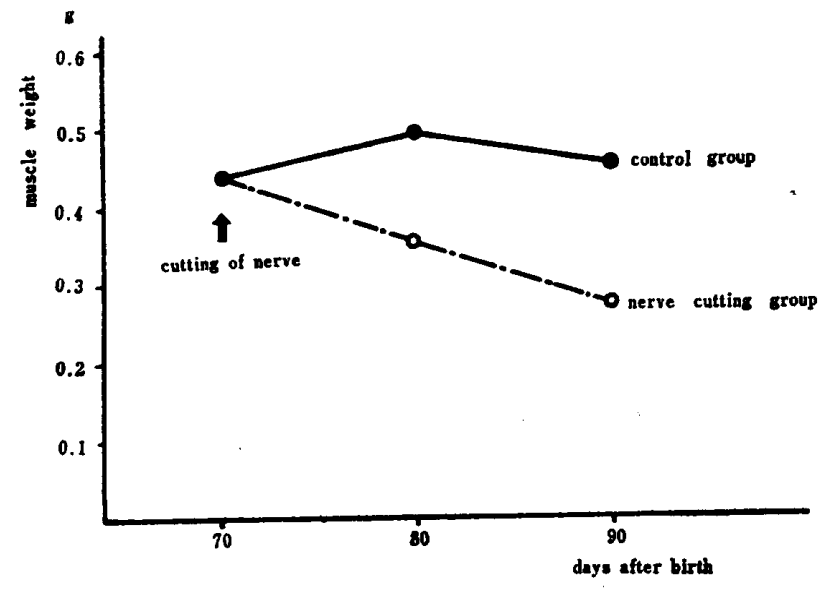

Fig. 2 Effect of Cutting of Nerve upon Weight of $\mathbf{M}$. tibialis ant.

る、ラットの体重には, 倠雄とも神経切断の影響 はみられなかった。

表 1 は, 下肢筋 M. tibialis ant., M. gastrocnemius, M. soleus, M. plantaris および M. ext. longus の各竻重量におよぼす神経切断の影 響を検討したものである.図 2 は，被検筋 M. ti- bialis ant. の筋重量の減少率を検討したものであ るが，神経切断後10日目で $28.4 \% ， 20$ 日目で39.8 \%の減少を示し，生後70日目を対照群として減少 率を求めると．神経切断後10日目で20.2\%，20日 目で38.2\%を示し， N. fiburalis profundus 切断 による M. tibialis ant. の重量減少は著るしい傾 向を示した。神経切断の傷害を直接うけない $\mathrm{M}$. gastrocnemius について筋重量の減少率を検討し た結果. 神経切断後10日目で4.4\%，20日目で6.1 \%の減少を示し. M. ext. longus では. 各々13.3 \%, 22.9\%であった. しかし, M. soleus, M. plantarisでは，神経切断の影響はほとんどみとめられ なかった。

2 ) M. tibialis ant. の全横断面積の変化

军真 1 は, 神経切断後10日目, 20 日目の M. tibialis ant. の組織像を示したものである. 神経切 断後10日目では, 赤筋線維, 中間筋線維の色調が やや褪せる程度で. 形の変形はみとめられなかっ 


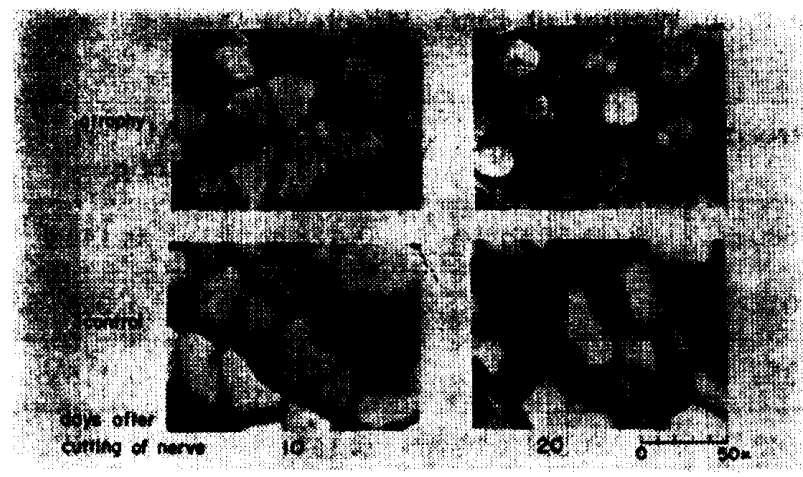

Photo. 1 Effect of Nerve Cutting upon Rats' Anterior Tibial Muscle Fibers of 70 days after birth
たが，神経切断後20日目になると，骨格筋線維は 全体として丸味を带びるようになり，さらに赤筋 線維, 中間筋線維扣よび白筋線維の竓別が困難で あった. そのために, 神経切断後 20 日目の M. tibialis ant. の全横断面積および一本あたりの平均 横断面積の測定をさけた。

表 2 および図 3 は，神経切断後10日目の M. tibialis ant. の全横断面積におよほすす影響を，赤筋 線維, 中間筋線維扣よび白筋線維について萎縮率 を求めて検討したものである。そその結果，赤筋線 維 $19.3 \%$ ，中間筋線維 $34.7 \%$, 白䈷線維 $43.7 \%$ を

Table 2 Effect of Cutting of Nerve upon Entire Area of Cross Section of Rats' Anterior Tibial Muscle Fibers

\begin{tabular}{|c|c|c|c|c|c|}
\hline \multirow{2}{*}{\multicolumn{2}{|c|}{ Group }} & \multirow{2}{*}{ Sex } & \multicolumn{3}{|c|}{ Entire area of cross section } \\
\hline & & & Red fibers & Medium fibers & White fibers \\
\hline & \multirow{3}{*}{$\begin{array}{l}\text { control group of } 70 \text { days } \\
\text { after birth }\end{array}$} & $\hat{o}$ & 3. $80 \mathrm{~mm}^{2}$ & $1.60 \mathrm{~mm}^{2}$ & $7.09 \mathrm{~mm}^{2}$ \\
\hline & & q & 2.92 & 1.07 & 4. 32 \\
\hline & & Mean & 3.36 & 1.34 & 5.71 \\
\hline \multirow{3}{*}{ (2) } & \multirow{3}{*}{$\begin{array}{l}\text { nerve cutting group of } 80 \\
\text { days after birth } \\
\left(\begin{array}{l}10 \text { days after nerve } \\
\text { cutting }\end{array}\right.\end{array}$} & $\hat{o}$ & 2.99 & 0.70 & 3.67 \\
\hline & & 우 & 3. 52 & 1.21 & 4.85 \\
\hline & & Mean & 3. 26 & 0.96 & 4.26 \\
\hline \multirow{3}{*}{ (3) } & \multirow{3}{*}{$\begin{array}{l}\text { control group of } 80 \text { days } \\
\text { after birth }\end{array}$} & $\hat{o}$ & 4.67 & 1.66 & 9.25 \\
\hline & & 9 & 3.41 & 1. 27 & 5.86 \\
\hline & & Mean & 4.04 & 1.47 & 7.56 \\
\hline
\end{tabular}

red muscle fibers

nerve cutting group

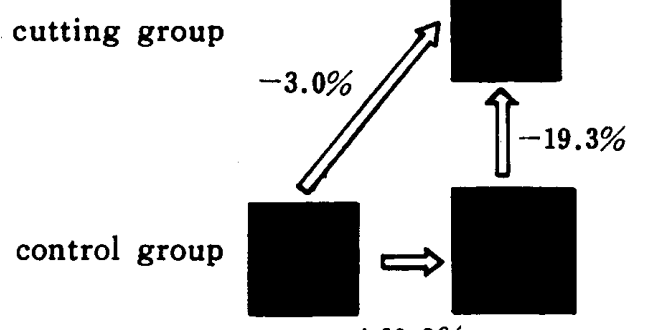

$+20.2 \%$

70

80

meduim muscle fibers

white muscle fibers

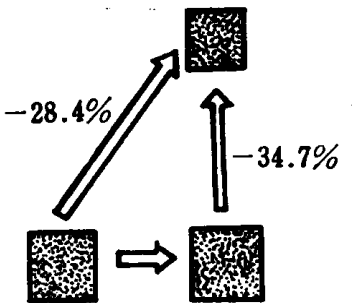

$+9.7 \%$

$70 \quad 80$

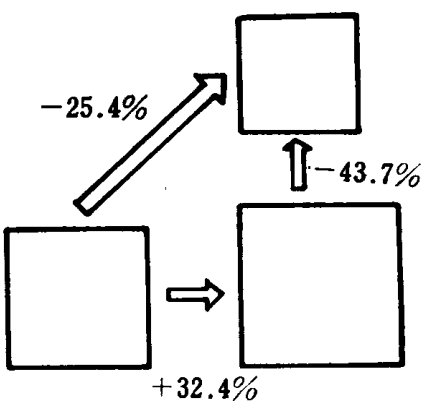

70

80

days after birth

Fig. 3 Effect of Nerve Cutting upon Entire Area of Cross Section of Rats' Anterior Tibial Muscle Fibers 


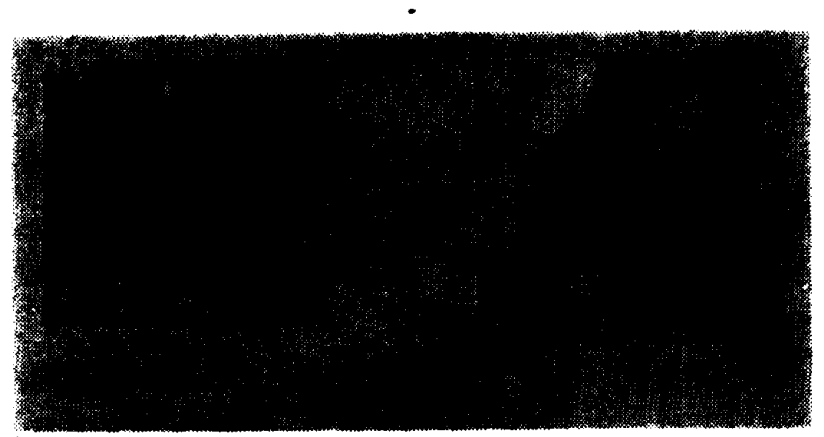

Photo. 2 Effect of Nerve Cutting upon Rats' Anterior Tibial Muscle Fibers of 150 days after birth
示し，特に白筇線維の荟縮が著るしく，次いで中 間筋線維，赤肪楾維の順に大をきかった。

写真 2 は. 生後150日の成熟後のラットについ $\tau, N$. fibularis profundus を切断してから10日 目の M. tibialis ant. の組織像を示したものであ る、明らかに，筋線維の変形と色調の変化がみら れ，成熟後の筋萎縮の速度は，生後70日の場合と 比べると早い傾向がみられた。

3) M. tibialis ant. 一本あたりの平均横断面

Table 3 Effect of Cutting of Nerve on Average Area of Cross Section per Fiber in Peripheral, Innermost and Whole regions of Rats' Anterior Tibial Muscle Fibers

\begin{tabular}{|c|c|c|c|c|c|c|c|c|c|c|c|}
\hline & & & \multicolumn{3}{|c|}{ peripheral } & \multicolumn{3}{|c|}{ innermost } & \multicolumn{3}{|c|}{ whole } \\
\hline & & & $\begin{array}{c}\text { red } \\
\text { fibers }\end{array}$ & $\begin{array}{c}\text { medium } \\
\text { fibers }\end{array}$ & $\begin{array}{l}\text { white } \\
\text { fibers }\end{array}$ & $\begin{array}{c}\text { red } \\
\text { fibers }\end{array}$ & $\begin{array}{c}\text { medium } \\
\text { fibers }\end{array}$ & $\begin{array}{l}\text { white } \\
\text { fibers }\end{array}$ & $\begin{array}{c}\text { red } \\
\text { fibers }\end{array}$ & $\begin{array}{c}\text { medium } \\
\text { fibers }\end{array}$ & $\begin{array}{l}\text { white } \\
\text { fibers }\end{array}$ \\
\hline \multirow{4}{*}{\multicolumn{2}{|c|}{$\begin{array}{l}\text { control group of } \\
\text { (1) } 70 \text { days after } \\
\text { birth }\end{array}$}} & $\delta$ & $\begin{array}{r}\boldsymbol{\mu}^{2} \\
839.5\end{array}$ & $\begin{array}{r}\mu^{2} \\
1031.0\end{array}$ & $\begin{array}{r}\mu^{2} \\
1472.0\end{array}$ & $\begin{array}{r}\mu^{2} \\
631.4\end{array}$ & $\begin{array}{r}\boldsymbol{\mu}^{2} \\
770.2\end{array}$ & $\begin{array}{r}\mu^{2} \\
928.2\end{array}$ & $\begin{array}{r}\boldsymbol{\mu}^{2} \\
711.5\end{array}$ & $\begin{array}{r}\mu^{2} \\
916.9\end{array}$ & \\
\hline & & & & & & & & & & & \\
\hline & & ? & 604.2 & 802.0 & 1079.7 & 521.4 & 756.3 & 890.8 & 556.3 & 778.9 & 1014.1 \\
\hline & & Mean & 721.9 & 916.5 & 1275.9 & 576.4 & 763.3 & 909.5 & 633.9 & 847.9 & 1149.5 \\
\hline \multirow{3}{*}{\multicolumn{2}{|c|}{ 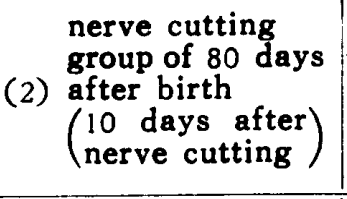 }} & $\delta$ & 620.9 & 660.6 & 859.8 & 609.7 & 664.9 & 766.5 & 614.9 & 662.6 & 829.6 \\
\hline & & & 633.8 & 719.7 & 921.7 & 514.5 & 735.7 & 814.7 & 567.7 & 727.2 & 889.0 \\
\hline & & Mean & 627.4 & 695.2 & 890.8 & 562.1 & 700.3 & 790.6 & 591.3 & 694.9 & 859.3 \\
\hline \multirow{3}{*}{\multicolumn{2}{|c|}{$\begin{array}{l}\text { control group of } \\
\text { (3) } 80 \text { days after } \\
\text { birth }\end{array}$}} & $\delta$ & 868.4 & 1083.8 & 1717.1 & 705.9 & 880.5 & 1224.2 & 766.4 & 965.7 & 1536.4 \\
\hline & & f & 640.6 & 799. 3 & 1210.4 & 528.9 & 732.1 & 793.0 & 571.8 & 763.3 & 1064.6 \\
\hline & & Mean & 754.5 & 941.6 & 1463.8 & 617.4 & 806.3 & 1008.6 & 669.1 & 864.5 & 1300.5 \\
\hline
\end{tabular}

red muscle fiber

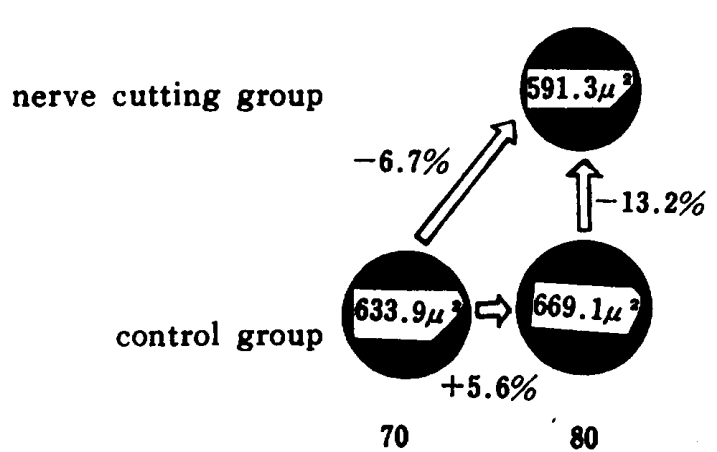

medium muscle fiber

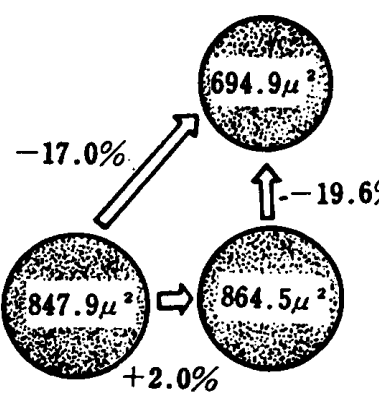

70

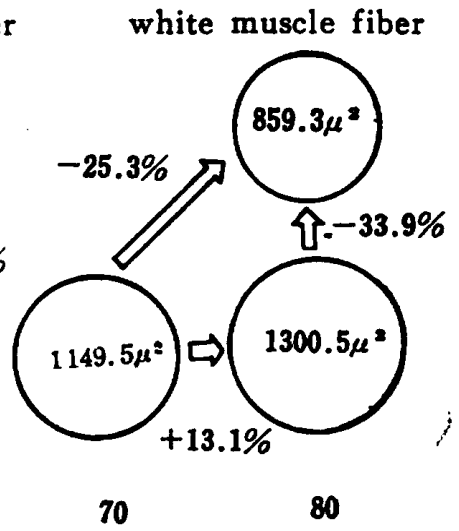

days after birth

Fig. 4 Effect of Cutting of Nerve upon Average Area of Cross Section per Fiber of Rats' Anterior Tibial Muscle Fibers 


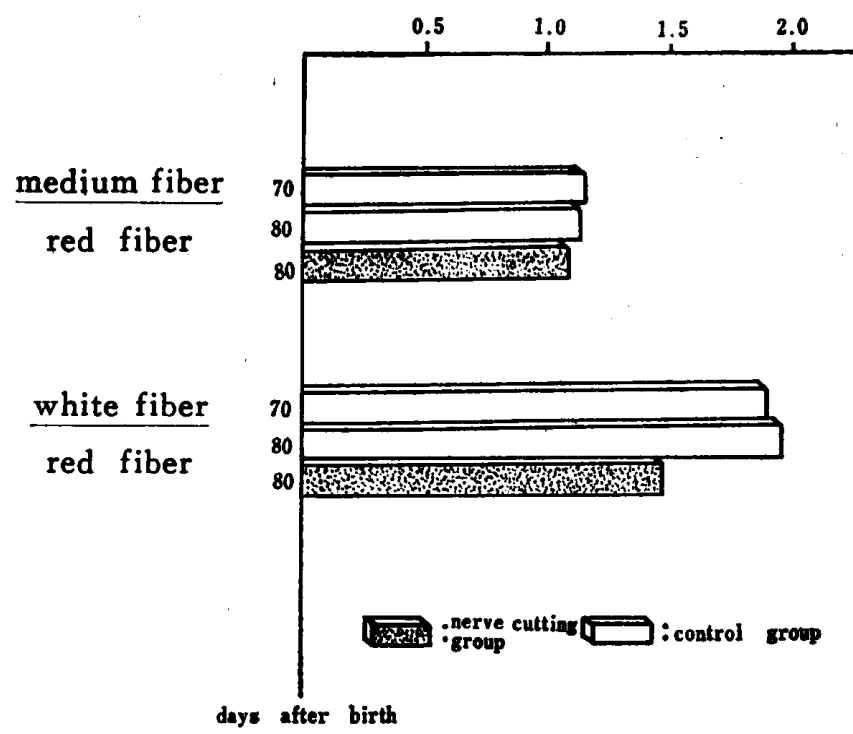

Fig. 5 Comparison of Ratio of Cross Section per Medium Fiber and White Fiber to Cross Section per Red Fiber

\section{積の変化}

表 3 および図 4 は，M. tibialis ant. の一本あた りの平均横断面積におよぼす神経切断の影響を， 赤筋楾維, 中間筋線維, 白筇線維について検討し たものである．神経切断後10日目の筋萎縮率を求 めると．赤筋線維 $13.2 \%$ ，中間筇線維 $19.6 \%$ ，白 筋線維 $33.9 \%$ を示したが，さらに生後 70日を対照 群として萎縮率を求めると，それでれ6.7\%，17.0 $\%, 25.3 \%$ を示し，白筋線維の萎縮する割合が一 番著明で，ついで中間筋線維，赤筋線維の㮌に大 きい值を示した。

観点をかえて，骨格筋線維のなかでも萎縮する 割合が最む小さい赤筋線維の一本あたりの平均横 断面積 (R) を基にして．白筋線維の平均横断面 積 (W) 拈よび中間筋楾維の平均横断面積 (M) との比, すなわち $W / R, M / R$ を求めて, 生後70 日の対照群，神経切断後10日目（生後80日）の実 験群および神経切断後 10日目の対照群について筋 萎縮の様相を検討した結果は，図 5 に示すとおり である.どの群においても，W/R の比率は，M/ $\mathrm{R}$ のそれより大きい傾向を示し，また W/R の 比率では, 神経切断後10日目の実験群が他の 対照 群に比べて小さい值を示した。この傾向は，神経 切断群の白筋線維の萎縮する割合が，中間筋楾維 や赤筋線維よりも大きいことを示唆するものであ る.
哺乳動物の骨格筋線維は, 赤筋線維, 中間㬳線 維および白筋線維の三種類から構成されているこ とは.すすで組織学的，組織化学的に解明されて いることである28)101115).

著者むか5)，ラットおよびマウスの M. tibialis ant.を用いて. Sudan black B 染色により骨格 筋線維を赤筋線維，中間筋線維お゙よび白筋線維に 分類し，それらの形態的特徵とその分布，さらに 筋トレーニングの影響について検討し，すでに報 告した。特に筋トレーニングに関しては，等張性 筋収縮を主とするトレッドミルを用いた動的筋ト レーニングにおいて，白筋線維の肥大する割合が 最も著るしく，ついで中間筋線維，赤筋線維の順 に大きいことが明らかとなった。

筋萎縮に関する資料として，Beckett 等1)は進 行性筋ジストロィー症で䍜患筋のコハク酸脱水 酵素活性の減少を報告したをはじめ，Nachmias 等8)は, 神経切断筋の phosphorylase の変化を調 へ，白筋線維のそれは赤筋線維より大きいと述べ ている。また最近では，南7)，日野3) は支配神経切 断や挫滅の骨格筇楾維にあたえる影響を検討し， 白筋線維の萎縮は赤筋線維よりも著明であったこ とを報告し，さらに末永 ${ }^{12}$ はギプス固定の際に招 来される筋萎縮についての電顕的検索を行い，同 様に白筋線維の萎縮する割合は赤筋線維よりも著 明であったと述べている。

以上の上5に，骨格筋線維を赤筋線維，白筋線 維に分けて筋萎縮の現象を追求しているものの, 中間筋線維の萎縮について検討した資料はなく， さらに被検筋全体について検索した文献はみられ ないのである.

本研究では, ラットの M. tibialis ant. 支支配 する N. fibularis profundus 切断後の筋萎縮の 様相を筋腹の全横断面積および一本あたりの平均 横断面積を筋楾維の種類毎に求めて検討したので あるが，南》，日野8) 等の報告と同じょうに白筋 線維の萎縮率は赤筋線維のそれより大きい值を示 した。また，中間筋線維の萎縮率は，白筋線維， 赤筋線維のそれらの中間的值を示したが。これら の傾向はすでに 報告している動的筋トレーニング 
の際の筋肥大の現象とよく似ているのである.す なわち，神経切断や筋トレーニングを骨格筋線維 に与える一つの stimulus と考えると，いずれの 場合でも。その stimulus に対する response は 白筋線維では一番大きく，ついで中間筋線維，赤 筋線維の順にあると考えられる。

白筋線維の萎縮率が赤筋線維のそれより大きい 理由の一つとして，つぎのことがあげられょ5。 Sréter ${ }^{13) 14)}$ は, 哺乳類の細胞内外の水分量, sodium および potassium のイオン濃度を検討し， 細胞外の sodium イオン濃度は白筋線維の方が赤 筋線維より高く，一方 potassium イオン濃度は， 白筋線維の力が赤筋線維より低い傾向がある。 た，外的な刺激を与えた㨁後の dehydration と sodium, potassium のイオン変化は, 白筋線維の 方が赤筋線維より著明であると報告している。中 間筋線維の細胞内外の水分量および sodium, potassium のイオン変化については，まだ明らかで ないので，ビうして中間筋線維の萎縮率が赤筋線 維と白筋線維の間の值を示したのかについては, 今後の課題として検討する予定である.

\section{総括}

同腹の Wistar 系ラットの雃雄を用い, 生後70 日目に M. tibialis ant. を支配する N. fibularis profundus を脛骨頭の部位で切断したのち，10日 目，20日目に筋萎縮の現象を組織学的に検討し。 次のような成績を得た。

1）神経切断による体重の減少はみとめられな い.

2 ) M. tibialis ant. の筋重量は, 神経切断後 10日目では $28.4 \% ， 20$ 日目で $39.8 \%$ の城少を示し た。また. M. gastrocnemius, M. ext. longus で は，筋重量の減少は僅かにみとめられたが。 $\mathrm{M}$. soleus および M. plantaris では殆んどみとめら れなかった。

3) M. tibialis ant. の筋腹に怙ける全横断面 積の萎縮率は。神経切断後 10 日目では赤筋線維 $19.3 \%$ ，中間筋線維 $34.7 \%$ ，白筋線維 $43.7 \%$ を示 した.

4 ） M. tibialis ant. の一本あたりの平均横断 面積の萎縮率は，神経切断後 10 日目で赤筋線維
$13.2 \%$ ，中間筋線維 $19.6 \%$ ，白筋線維 $33.9 \%$ を示 し. 全横断面積の場合と同じょうな傾向を示し た。

（本論文要旨は，第21回日本体育学会で発表した.）

\section{套文献}

1) Beckett, E.B. and Bourne, G.H.: Histochemistry of skeletal muscle and changes in some muscle diseases, Structure and function of muscle, Vol. 3, 275-320, Ed. Bourne, G.H., Academic press, 1960.

2) Henneman E. and Olson C.B. : Relations between structure and function in the design of skeletal muscles, J. Neurophysiol., Vol. 28, 581598,1965

3）日野博夫：末梢神経拉よび骨格筋飞外科的侵蚝を加 えた際に挌ける骨格筋の变化飞関する細胞学的研究, 第三編踺切断おっよびギプス固定における骨格筋線維の 変化炕関する組織化学的研究, 岡山医学誌, Vol. 910, $571-578,1969$.

4）菊地邦雄：筋トレーニングの組織学的研究一静的筋 トレーニングと動的筋トレーニングの骨格筋線維に及 ほす影響の比挍一, 体育学研究, Vol. 16, No. 2, 67 $-74,1971$.

5）菊地邦雄：中間筋線維に及ほす筋トレーニングの影 慗儿関する組織学的研究, 体力科学, Vol. 22, No. 1, 17-25, 1973.

6) M. Man-i, K. Ito, and K. Kikuchi : Histological studies of muscular training, Report 1 Effect of training upon skeletal muscles fibers, Research Journal of Physical Education, Vol. 11, No. 3, 153-165, 1967.

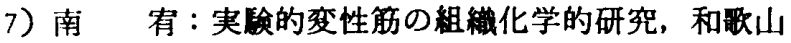
医学, Vol. 17, No. 1, 137-148, 1966.

8) Nachmias, V.I. and Padykula, H.A. : A histochemical study of normal and denervated red and white muscles of the rat, J. Biophy. Biochem. Cytol., Vol. 4, 47-54.

9）岡本耕造，上田政雄，，前田隆英：顕徽鏡的組織化 学, 医学書院, 276-277, 1955.

10) Ogata T. and Mori, M.: Histochemical Study of Oxidative Enzymes in Vertebrate Muscles, Journal of Histochemistry and Cytochemistry, Vol. 12, No. 3, 171-182, 1964.

11) Ogata T., and Mori. M.: Histochemical Study 
of Oxidative Enzymes in Vertebrate Muscles, J. Histochemistry and Cytochemistry, Vol. 12, 171$182,1964$.

12）末永政治：骨格筋の機能組維学的研究，第 2 相ギプ ス固定による筋荟缩とその回復過程についての光頙的 ならびK菓㩆的㭘索, 鹿児岛大学医学誌, Vol.20,No. 4, 864-877, 1969.

13) Sréter F.A. and Woo, G.: Cell water, sodium, and potassium in red and white mammalian muscles, Am. J. Physiol. Vol. 205, No. 6, 1290-
$1294,1963$.

14) Sréter F.A.: Cell water, sodium, and potassium in stimulated red and white mammalian muscles, Am. J. Physiol. Vol. 205, No. 6, 12951298, 1963.

15) Stein J.M. and Padykula H.A. : Histochemical classification of individual skeletal muscle fibers of the rat, Am. J. Anatomy, Vol. 110, 103-123, 1962. 